professional development. taking into account that the process of self-study occurs during independent work of students, one can note that self-study can be regarded as a goal and result of activity, whereas independent work is seen as a means to achieve the result. It is pointed out that under today's conditions independent work does not properly fulfil the tasks it should since it lacks purposefulness, focus on problem-solving, educational and methodological and technical support, is poorly monitored, insufficiently differentiated and variable. The paper emphasizes that unlike independent work, self-study involves not only activities aimed at absorbing, deepening and acquiring new knowledge during higher education study. It is also a form of continuing education for young specialists after graduation.

Therefore, further research should focus on improving organization of future teachers' independent work.

Key words education, self-education, students' independent work, self-cognition.

удк 355.233:796(477)

\author{
Дмитро Погребняк \\ Національний університет оборони \\ України імені Івана Черняховського \\ ORCID ID 0000-0001-8364-663X \\ Денис Коновалов \\ Національний університет оборони \\ України імені Івана Черняховського \\ ORCID 0000-0002-8563-1121 \\ DOI 10.24139/2312-5993/2020.01/276-288
}

\title{
МЕТОДИКА РОЗВИТКУ ФАХОВОЇ КОМПЕТЕНТНОСТІ НАЧАЛЬНИКІВ ФІЗИЧНОЇ ПІДГОТОВКИ ТА СПОРТУ ВІЙСЬКОВИХ ЧАСТИН ЗБРОЙНИХ СИЛ УКРАЇНИ В СИСТЕМІ ПІСЛЯДИПЛОМНОЇ ОСВІТИ
}

Стаття присвячена теоретичному обгрунтуванню авторської методики розвитку фахової компетентності начальників фізичної підготовки та спорту військових частин збройних сил України (далі - НФПіС) у системі післядипломної освіти. Методи дослідження: аналіз наукової літератури; узагальнення й інтерпретація отриманих теоретичних і емпіричних даних; проєктування методики розвитку фахової компетентності. Розкрито основні етапи методики: ціннісномотиваційний; теоретичний; практичний; творчо-рефлексивний. Запропонована методика сприятиме поглибленню та систематизації теоретичних знань, розвитку практичних навичок, умінь і здібностей.

Ключові слова: фрахова компетентність, розвиток, методика розвитку, начальник фрізичної підготовки та спорту, етапи, методи, засоби.

Постановка проблеми. Перехід системи підготовки Збройних сил України на стандарти, які прийняті в арміях держав-членах НАТО (на 20192022 роки), потребує перегляду методологічних підходів, теоретичних основ і сучасних методик підготовки офіцерського складу, передбачає розмежування оперативного та стратегічного рівнів як підготовки, так і 
підвищення кваліфікації, а також запровадження курсової підготовки за рівнями навчання та перед обійманням офіцерами конкретної посади.

У сучасних Збройних силах України існує суттєвий попит на висококваліфікованих НФПіС, здатних якісно планувати та організувати фізичну підготовку особового складу. Слід зазначити, що від рівня розвиненості їх фахової компетентності залежить якість підготовленості військовослужбовців до виконання повсякденних і бойових завдань за призначенням. В умовах збройної агресії Російської Федерації щодо нашої держави підготовка фахівців фізичної підготовки та спорту має спрямовуватися на підвищення якості їх фахової компетентності, практичної готовності до вирішення завдань військово-професійної діяльності.

у зв'язку з цим необхідність системного розвитку фахової компетентності НФПіС $€$ актуальною проблемою професійної педагогіки та освіти.

Аналіз актуальних досліджень довів, що проблема розвитку фахової компетентності НФПіС знайшла часткове відображення в наукових дослідженнях. Так, розвиток військово-спеціальної компетентності офіцерів досліджував В. Веретільник, фахову компетентність офіцерів О. Чернявський, формування фахової компетентності різних фахівців В.Ягупов, Д.Костюк, розвиток професійної компетентності фахівців фізичної культури та спорту присвячені роботи О. Завальнюк і С. Агеєва, проблема забезпечення педагогічної ефективності підвищення їх кваліфікації - наукові напрацювання Б. Лосина. Проте методика розвитку фахової компетентності НФПіС досліджено науковцями недостатньо.

Таким чином, актуальність обґрунтування методики розвитку фахової компетентності НФПіС у системі післядипломної освіти підтверджено, а розв'язання цієї проблеми сприятиме покращенню їх фахової підготовки.

Метою статті $\epsilon$ теоретичне обґрунтування методики розвитку фахової компетентності НФПіС у системі післядипломної освіти.

Методи дослідження: аналіз наукової літератури з проблеми дослідження; узагальнення й інтерпретація отриманих у процесі дослідження теоретичних іемпіричних даних; проєктування методики розвитку їх фахової компетентності в системі післядипломної освіти.

Виклад основного матеріалу. В умовах суттєвого підвищення ролі Збройних сил України і функціонування України як міжнародного суб'єкта розвиток фахової компетентності НФПіС має здійснюватися неперервно в системі військової освіти. Складовою цієї системи є післядипломна освіта, яка має за мету перепідготовку фахівців, розвиток і вдосконаленні їх фахової компетентності, допомогу в самореалізації у військовопрофесійній діяльності. Структурним елементом післядипломної освіти НФПіС $є$ підвищення їх кваліфікації, метою якого $є$ оновлення, відновлення й поглиблення їх фахових знань, умінь і навичок, збагачення військовопрофесійної та фахової культури. 
У процесі розроблення методики розвитку фахової компетентності НФПіС усистемі післядипломної освіти ми дотримувалися методичних рекомендацій таких провідних учених, як О. Бойко, Г. Селевко, О. Сіроштан, С. Сисоєва, О.Пометун, В. Ягупов. Також для нашого дослідження суттєвий інтерес представляють наукові праці провідних теоретиків і методистів вітчизняної системи фізичного виховання та спорту - Ю. Верхошанського, Т. Круцевич, Л. Матвєєва, М. Набатнікової, В. Платонова, Л. Сергієнка, Б. Шияна та ін.

Аналіз сутності поняття «методика» показує різні підходи науковців до його розуміння. Маються такі варіанти його розуміння як: галузь педагогічної науки, яка досліджує закономірності вивчення певного навчального предмета (Гончаренко, 1997); сукупність взаємопов'язаних способів і прийомів доцільного проведення будь-якої роботи; вчення про методи викладання певної науки, предмета (Бибик та Сюта, 2005); конкретні форми й засоби використання методів, за допомогою яких здійснюється все глибше пізнання різноманітних педагогічних проблем і їх розв'язання (Ягупов, 2000); спеціально упорядкована сукупність методів, методичних прийомів, засобів і форм навчання (Шиян, 2008).

Основою методики навчання $\epsilon$, на думку О.Бойка (Бойко, 2005, с. 136), «ідея керування дидактичним процесом, проектування й відтворення навчального циклу».

Г. Селевко (Селевко, 1998, с. 86) вважає, що методика має відповідати таким методологічним вимогам: «концептуальності (має спиратися на певну наукову концепцію, що включає філософський, дидактичний і соціальнопедагогічний аспекти досягнення цілей); системності (мають простежуватися всі ознаки системи: логіка процесу, взаємозв'язки ії частин, цілісність); керованості (передбачає можливість діагностичного цілепокладання, проектування процесу навчання, поетапної діагностики, варіювання засобами й методами з метою коригування результату); ефективності (бути ефективною за результатами й оптимальною за витратами, гарантувати досягнення певного стандарту); відтворюваності (наявність можливості застосування, відтворення іншими)».

Ключовим компонентом методики розвитку фахової компетентності НФПіС є методи навчання. Поняття метод (від грец. methodos - шлях дослідження, теорія, вчення) - це систематизований спосіб досягнення теоретичного чи практичного результату, розв'язання проблеми чи одержання нової інформації на основі певних регулятивних принципів пізнання та дії, усвідомлення специфіки досліджуваної предметної галузі й законів функціонування їі об'єктів (Шинкарук, 2002); сукупність прийомів і способів психолого-педагогічного впливу на студентів, які спрямовані на розвиток у них творчого самостійного мислення, активізацію пізнавальної діяльності, формування творчих навичок і вмінь нестандартного розв'язання 
певних професійних проблем та вдосконалення навичок професійного спілкування (Ягупов, 2000); спосіб виконання конкретної вправи або застосування інших засобів (слово, показ), які забезпечують досягнення поставленої мети (розвиток якостей, навчання, контроль) (Круцевич, 2008).

На даному етапі розвитку педагогіки існує багато різноманітних підходів до виявлення сутності методів навчання, їх визначень і структури, що породжує проблему їх класифікації. Значний внесок у розвиток теорії методів навчання зробили Є. Голант, М. Данилов, М. Скаткін, М. Лернер, А. Алексюк, В. Паламарчук та ін. У дидактиці існують різні підходи до класифікації методів навчання. Поширеними є класифікації методів за джерелом знань (Д. О. Лордкіпанідзе, С. Я. Голант, Н. М. Верзілн та ін.); за характером логіки пізнання (І.Я.Лернер); за рівнем проблемності засвоєння знань і рівнем учіння (М.І. Махмутов); на основі цілісного підходу до процесу (Ю. К. Бабанський), за логікою викладання педагога та пізнавальної діяльності учнів (курсантів, слухачів) (В. В. Ягупов).

Теоретичний аналіз проблеми дослідження дозволив зробити висновок, що методика розвитку фахової компетентності НФПіС у системі післядипломної освіти - це комплекс принципів, методів, видів навчальних занять, організаційних форм навчання й засобів їі розвитку, що сприятиме систематизації та поглибленню теоретичних знань військово-професійного та фахового спрямування, розвитку фахових навичок, умінь і здібностей, професійно важливих якостей як суб'єктів специфічної військовопрофесійної діяльності у військах.

Під час розроблення авторської методики нами поставлені такі цілі:

сприяти розвитку ціннісного ставлення НФПіС до свого фаху як важливої передумови військово-професійної діяльності, прагнення до отримання практичного досвіду фахової діяльності, розвиток фахових знань, умінь і навичок;

сприяти створенню умов для цілеспрямованого розвитку теоретичних основ їх фахової компетентності в системі післядипломної освіти;

сприяти розширенню їх фахових знань, практичних фахових умінь, навичок, професійно важливих якостей і здібностей.

У процесі розроблення цієї методики враховано основні положення системного, компетентнісного, андрагогічного, суб'єктно-діяльнісного та контекстного підходів, а також вимоги загально-дидактичних і специфічних принципів навчання військовослужбовців (Ягупов, 2000).

Крім цього ефективність цієї методики підвищується шляхом використання технології інтерактивного, проблемно-ситуативного навчання та застосування інформаційно-комунікаційних технологій.

Термін «інтерактивний» означає сприяти, взаємодіяти чи знаходитися в режимі дискусії, бесіди, обговорення з будь-чим, чи будь з ким. Інтерактивне навчання - це, передусім, діалогове навчання, в процесі якого здійснюється 
взаємодія викладача й того, хто вчиться (Г.Гапоненко, С. Гапоненко, Погребняк, Родіков та Шемчук, 2018). Сутність інтерактивного навчання полягає в тому, що освітній процес відбувається за умови постійної активної взаємодії всіх його учасників. На думку О. В. Сіроштан (Сіроштан, 2012), воно спрямоване на забезпечення спільної навчальної діяльності, отримання знань, розвитку вмінь, навичок, здобуття необхідних здатностей у спільній діяльності через діалог, полілог офіцерів між собою та викладачем, а також шляхом прямої взаємодії 3 навчальним оточенням або освітнім середовищем, що забезпечує високий рівень мотивації слухачів до навчальної діяльності та дає можливість моделювати професійну реальність.

Застосування активних методів навчання дає можливість організувати роботу слухачів у парах, трійках, малих групах, використовувати «карусель», «акваріум», коли реалізуються методичні елементи інтерактивних технологій колективно-групового навчання «мікрофон», «незакінчені речення», «мозковий штурм», «ажурна пилка», «кейс-метод», «дерево рішень» тощо. Військовий контекст дає можливість реалізувати інтерактивні технології ситуативного моделювання - симуляції, імітаційні та ділові ігри, а також застосовувати інтерактивні технології опрацювання дискусійних питань (Ягупов, 2000).

Таким чином, використання інтерактивних методів навчання в процесі розвитку фахової компетентності НФПіС у системі післядипломної освіти сприяє розвитку внутрішньої мотивації, стимуляції розумової діяльності, розвитку фахових навичок і вмінь, активізації навчальнопізнавальної діяльності та створює сприятливі обставини для їх творчого професійного розвитку.

Авторська методика розвитку фахової компетентності ґрунтується на методичних прийомах методики проблемно-ситуативного та контекстного навчання, яка передбачає використання типових фахових проблем i ситуацій, під час розв'язання яких НФПіС вчаться застосовувати отримані теоретичні знання на практиці, розвивають професійні та фахові вміння, професійно важливі якості, необхідні їм для успішної військовопрофесійної діяльності.

Як зазначає В. Стасюк (Стасюк, 2013), використання сучасних IKT, нарощування дослідницького, експериментального потенціалу мають розглядатися як основа підготовки військових фахівців і провідний інструментарій покращення якості вищої військової освіти.

У процесі педагогічного експерименту виявлено, що реалізації методики розвитку фахової компетентності НФПіС у системі післядипломної освіти сприяє впровадження спецкурсу «Основи фахової діяльності НФПіС». Основними завданнями спецкурсу $\epsilon$ підвищення рівня фахових теоретичних знань іпрактичних умінь 3 основ організації спортивно-масової роботи у військових частинах, 
методики підготовки окремих спортсменів і збірних команд військової частини до участі в спортивних змаганнях.

До змісту курсу включено такі теми:

Тема 1. «Начальник фізичної підготовки і спорту: роль, місце та основні функції в системі фізичної підготовки військ (сил)».

Тема 2. «Методика реалізації посадових компетенцій НФПіС щодо фізичної підготовки особового складу військової частини».

Тема 3. «Методика організації та проведення спортивно-масової роботи у військовій частині».

Тема 4. «Методика підготовки окремих спортсменів і збірних команд військових частин до спортивних змагань».

Спецкурс починається зі вступного заняття, що спрямовано на активізацію навчально-пізнавальної діяльності НФПіС і визначення рівня розвиненості компонентів їх фахової компетентності. Слухачам курсу пропонується навчальний тест на виявлення рівня загальних знань за фахом, основних положень управління процесом фізичного вдосконалення військовослужбовців; тестування на визначення культури поведінки у військово-професійній діяльності. Під час вивчення спецкурсу основними й найбільш ефективними видами навчальних занять $€$ семінарські, групові та практичні заняття.

Пропонуємо авторську методику розвитку фахової компетентності НФПіС реалізовувати в чотири етапи: ціннісно-мотиваційний, теоретичний, практичний ітворчо-рефлексивний. Під етапом ми розуміємо проміжок часу й сукупність навчально-виховних заходів, спрямованих на розвиток їх фахової компетентності. Кожний з етапів має свою мету, завдання, основні методи й засоби, а також види навчальних занять (табл. 1).

Ціннісно-мотиваційний етап: метою є підвищення мотивації до фахової діяльності та забезпечення ціннісного ставлення до активності в навчальній діяльності. Основні завдання етапу такі: сприяння усвідомленню ними своїх цінностей діяльності як НФПіС, прагненню реалізовувати у фаховій діяльності професійні й особистісні настанови; позитивне ставлення до свого фаху; свідоме виконання функціональних обов'язків, прагнення розвивати фахові знання, досягнути високого рівня розвиненості фахової компетентності як суб'єкта фахової діяльності; мотивування до активної навчально-пізнавальної діяльності в процесі розвитку фахової компетентності. 
ЕТАПИ

Таблиця 1

методики розвитку фахової компетентності НФПіС у системі післядипломної освіти

\begin{tabular}{|c|c|c|c|c|}
\hline 穷 & Мета & Завдання & $\begin{array}{c}\text { Методи } \\
\text { та засоби }\end{array}$ & $\begin{array}{c}\text { Вид } \\
\text { навчальних } \\
\text { занять }\end{array}$ \\
\hline 1 & 2 & 3 & 4 & 5 \\
\hline 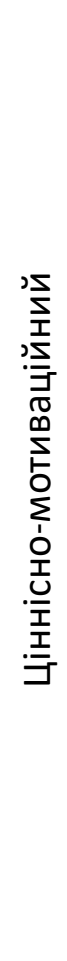 & $\begin{array}{l}\text { Підвищення } \\
\text { мотивації } \\
\text { НФПіС до } \\
\text { фахової } \\
\text { діяльності й } \\
\text { активності в } \\
\text { навчанні }\end{array}$ & $\begin{array}{l}\text { Сприяти: усвідомленню своїх } \\
\text { цінностей діяльності як НФПіС, } \\
\text { прагненню реалізовувати у } \\
\text { фаховій діяльності професійні й } \\
\text { особистісні настанови та } \\
\text { цінності; } \\
\text { позитивному ставленню до } \\
\text { фаху НФПіС; } \\
\text { свідомому виконанню } \\
\text { функціональних обов'язків, } \\
\text { прагненню розвивати фахові } \\
\text { знання, досягнути високого } \\
\text { рівня розвиненості фахової } \\
\text { компетентності як суб'єкта } \\
\text { фахової діяльності; } \\
\text { мотивації до активної } \\
\text { навчально-пізнавальної } \\
\text { діяльності в процесі розвитку } \\
\text { фахової компетентності }\end{array}$ & $\begin{array}{l}\text { Навчальна } \\
\text { бесіда, дискусія, } \\
\text { навіювання, } \\
\text { заохочення, } \\
\text { особистий } \\
\text { приклад } \\
\text { викладача, } \\
\text { анкетування, } \\
\text { тестування, } \\
\text { самоконтроль, } \\
\text { самооцінювання }\end{array}$ & $\begin{array}{l}\text { Лекційне, } \\
\text { групове, } \\
\text { семінарське, } \\
\text { практичне }\end{array}$ \\
\hline 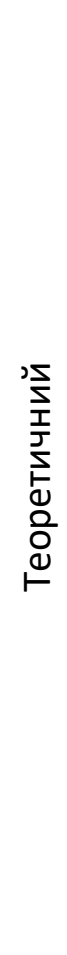 & $\begin{array}{l}\text { Розширен- } \\
\text { ня } \\
\text { поглиблення } \\
\text { фахових } \\
\text { знань }\end{array}$ & 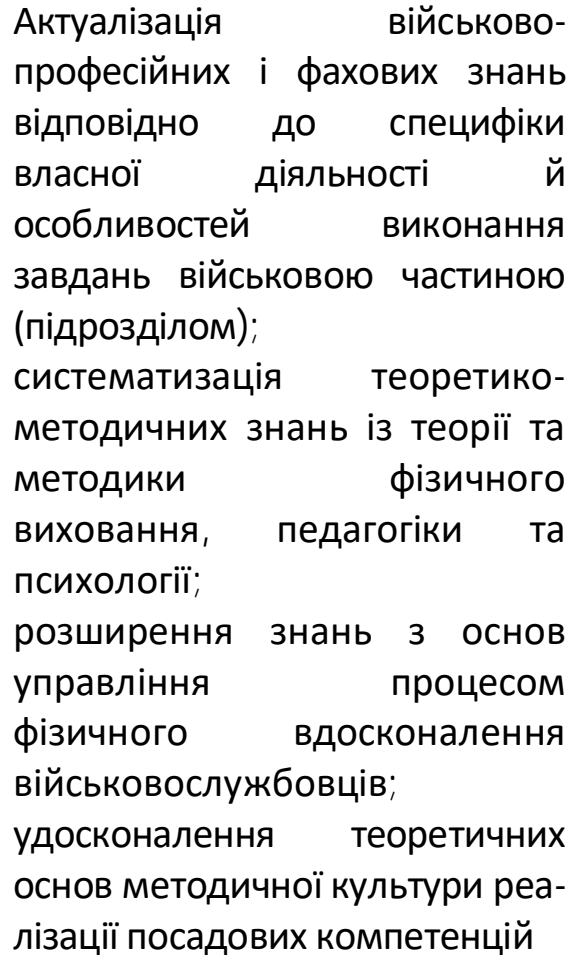 & $\begin{array}{l}\text { Самостійна } \\
\text { робота, } \\
\text { вивчення } \\
\text { спеціальної } \\
\text { літератури, } \\
\text { навчально- } \\
\text { пізнавальні ігри, } \\
\text { IКT, презентації, } \\
\text { навчальні бесіди } \\
\text { та дискусії, } \\
\text { тестування, } \\
\text { самоконтроль, } \\
\text { самооцінювання }\end{array}$ & $\begin{array}{l}\text { Лекційне, } \\
\text { групове, } \\
\text { семінарське, } \\
\text { самостійне }\end{array}$ \\
\hline
\end{tabular}


Педагогічні науки: теорія, історія, інноваційні технології, 2020, № 1 (95)

\begin{tabular}{|c|c|c|c|c|}
\hline 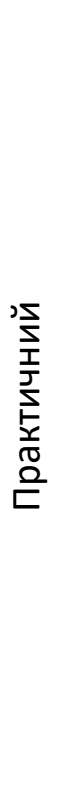 & $\begin{array}{l}\text { Розвиток } \\
\text { професійних } \\
\text { і фахових } \\
\text { умінь і } \\
\text { здібностей } \\
\text { офіцерів на } \\
\text { основі } \\
\text { набутих } \\
\text { теоретичних } \\
\text { знань }\end{array}$ & $\begin{array}{l}\text { На основі отриманих знань } \\
\text { сприяти розвиткові: } \\
\text { фахового мислення, досвіду } \\
\text { практичної діяльності; } \\
\text { фахових умінь з організаційно- } \\
\text { педагогічної, спортивної, } \\
\text { науково-дослідної роботи; } \\
\text { фахових здатностей організації } \\
\text { та проведення заходів } \\
\text { фізичної підготовки; } \\
\text { професійно важливих якостей } \\
\text { і підвищенню власного рівня } \\
\text { фізичної підготовленості }\end{array}$ & $\begin{array}{l}\text { Навчальний } \\
\text { тренінг, вправи, } \\
\text { навчальна } \\
\text { дискусія, } \\
\text { навчально- } \\
\text { рольова і ділова } \\
\text { гра, ІІТ, показ і } \\
\text { демонстрація } \\
\text { фізичних вправ, } \\
\text { особистий } \\
\text { приклад } \\
\text { викладача, } \\
\text { перегляд відео } \\
\text { матеріалів, } \\
\text { контроль } \\
\text { самоконтроль }\end{array}$ & $\begin{array}{l}\text { Групове, } \\
\text { практичне, } \\
\text { самостійне }\end{array}$ \\
\hline 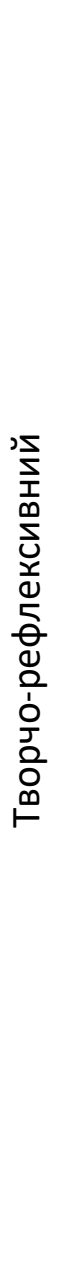 & $\begin{array}{l}\text { Розвиток } \\
\text { загальних і } \\
\text { спеціальних } \\
\text { фахових } \\
\text { умінь і } \\
\text { здібностей } \\
\text { НФПіС } \\
\text { об'єктивної } \\
\text { самооцінки } \\
\text { у звичайних } \\
\text { та ектремальн } \\
\text { екст умовах } \\
\text { их у умо } \\
\text { військово- } \\
\text { професійної } \\
\text { діяльності }\end{array}$ & $\begin{array}{l}\text { розвиток практичних умінь } \\
\text { самостійного } \\
\text { самооцінювання; } \\
\text { сприяння здатності мислити й } \\
\text { діяти як НФІПіС, об'єктивно } \\
\text { сприймати самого себе як } \\
\text { суб'єкта фахової діяльності, } \\
\text { вибирати оптимальну } \\
\text { стратегію поведінки в типових } \\
\text { і складних ситуаціях фахової } \\
\text { діяльності, визначати свій } \\
\text { емоційний стан і стан інших, } \\
\text { ураховувати його в процесі } \\
\text { організації спільної діяльності } \\
\text { и реалізації посадових } \\
\text { обов'язків; } \\
\text { розвиток умінь корегувати } \\
\text { свою діяльність, визначати } \\
\text { шляхи досягнення цілей; } \\
\text { сприяння професійному } \\
\text { ставленню до самого себе як } \\
\text { до суб'єкта фахової діяльності } \\
\text { та обраного фаху, прагненню } \\
\text { до фахового вдосконалення й } \\
\text { саморозвитку }\end{array}$ & $\begin{array}{l}\text { Навчальний } \\
\text { тренінг, аналіз } \\
\text { професійних } \\
\text { навчальних } \\
\text { ситуацій, } \\
\text { дискусія, } \\
\text { рольова й ділова } \\
\text { гра, IКТ, } \\
\text { методичні } \\
\text { прийоми } \\
\text { «акваріум», } \\
\text { «мозковий } \\
\text { штурм», } \\
\text { «круглий стіл», } \\
\text { вправи, методи } \\
\text { контролю та } \\
\text { самоконтролю }\end{array}$ & $\begin{array}{l}\text { Семінарське, } \\
\text { практичне }\end{array}$ \\
\hline
\end{tabular}

На цьому етапі застосовували такі види навчальних занять: навчальна бесіда, дискусія, навіювання, заохочення, повчальні історії, особистий приклад викладача. Застосування такого прийому як стимулювання сприяє розвитку мотиваційної складової фахової компетентності, позитивному ставленню до навчальної діяльності. Використання навчальних бесід і дискусій дозволяє визначати основні фахові потреби, уміння, професійно 
важливі якості, необхідні для успішного виконання фахових завдань, характер імовірних дій у стандартних і нестандартних ситуаціях діяльності. Зауважимо, що стимулювання інтересу тих, хто вчиться, здійснюється на всіх етапах розвитку фахової компетентності.

Теоретичний етап: мета - розширення й поглиблення фахових знань. Основні завдання такі: актуалізація та розвиток військово-професійних і фахових знань відповідно до специфіки власної діяльності та особливостей виконання завдань військовою частиною (підрозділом); систематизація теоретико-методичних знань з теорії та методики фізичного виховання, педагогіки та психології; розширення знань з основ управління процесом фізичного вдосконалення військовослужбовців; удосконалення теоретичних основ методичної культури реалізації посадових компетенцій.

Видами навчальних занять на теоретичному етапі $\epsilon$ лекційне, групове, семінарське та самостійне заняття. Ми вважаємо, що найбільш ефективним видом на цьому етапі $€$ семінарське занятт, яке передбачає самостійне вивчення слухачами окремих питань і тем дисципліни 3 подальшим відповідним оформленням матеріалу у вигляді реферату, доповіді чи в інший спосіб презентації вивченого матеріалу. Найпоширеніші його різновиди такі: семінар-диспут (дискусія), семінаррозгорнута бесіда, семінар-доповідь (повідомлення), семінар-«круглий стіл», семінар-«мозковий штурм», семінар-конференція, семінар-пресконференція, коментоване читання, обговорення рефератів і творчих письмових робіт, семінар-розв'язування задачі.

Нами з'ясовано, що під час вивчення теоретичних положень тем «Методика організації та проведення спортивно-масової роботи у військовій частині» і «Методика підготовки окремих спортсменів та збірних команд військових частин до спортивних змагань» найбільш результативними $\epsilon$ семінар-«круглий стіл». У свою чергу, тема «Методика реалізації посадових компетенцій НФПіС щодо фізичної підготовки особового складу військової частини», не містить значного об'єму теоретичного матеріалу, тому ми пропонуємо використовувати семінаррозгорнуту бесіду та практичні заняття.

На цьому етапі ми пропонуємо застосовувати такі види навчальних занять: самостійне вивчення спеціальної літератури, навчально-пізнавальні ігри, ІКТ, метод презентацій, навчальні бесіди та дискусії, метод усного контролю, тестування, самоконтроль, самооцінювання.

Практичний етап: мета - розвиток професійних і фахових умінь іздібностей офіцерів на основі набутих теоретичних знань. Основні завдання такі: сприяння розвитку фахового мислення, досвіду практичної діяльності; розвиток фахових умінь з організаційно-педагогічної, спортивної роботи; розвиток фахових здатностей організації та проведення заходів фізичної підготовки; розвиток професійно важливих якостей. 
Видами навчальних занять на цьому етапі $€$ : групове, практичне та самостійне заняття. Групове заняття - це вид навчального заняття, під час якого викладач пояснювально-лекційним методом подає новий навчальний матеріал, шляхом опитування контролює засвоєння слухачами цього матеріалу та сприяє його закріпленню. На цьому занятті викладач поетапно подає новий матеріал із теоретичних питань, супроводжує його демонстрацією та показом зразків озброєння та військової техніки, їх вузлів, блоків, діючих моделей, макетів тощо. Потім організовується обговорення цього матеріалу та здійснюється контроль рівня його закріпленню. У свою чергу практичне заняття - це вид навчального заняття, під час якого викладач організовує засвоєння слухачами, теоретичних положень навчальної дисципліни шляхом індивідуального виконання спеціально сформульованих завдань та сприяє формуванню в них умінь і навичок практичного застосування цих теоретичних положень. Воно включає проведення попереднього контролю знань, умінь і навичок тих, хто вчиться, постановку загальної проблеми викладачем та її обговорення, розв'язування контрольних завдань, їх перевірку та оцінювання (Наказ Міністерства оборони України № 346, 2015).

На цьому етапі пропонуємо застосовувати такі види навчальних занять: навчальний тренінг, вправи, навчальна дискусія, ділова гра, показ і демонстрація фізичних вправ, особистий приклад викладача, перегляд відеоматеріалів, контроль і самоконтроль.

Творчо-рефлексивний етап: мета - розвиток загальних і спеціальних фахових умінь і здібностей НФПіС щодо об'єктивного самооцінювання у звичайних та екстремальних умовах військово-професійної діяльності. Основні завдання: сприяння розвитку їх практичних умінь самооцінювання як НФПіС; сприяння розвитку в них здатності мислити й діяти фахівцю, об'єктивно сприймати самого себе як суб'єкта фахової діяльності, об'єктивно самооцінювати та вибирати оптимальну стратегію поведінки в типових і складних ситуаціях фахової діяльності, визначати свій емоційний стан і стан інших, ураховувати його в процесі реалізації посадових обов'язків; розвивати вміння корегувати свою діяльність, визначати шляхи досягнення цілей; сприяти професійному ставленню до самого себе як до суб'єкта фахової діяльності та обраного фаху.

Основним видом навчальних занять $є$ практичні заняття, а також ділова гра, на яких переважають вправи практичного характеру, що спрямовані на розвиток умінь і здібностей реалізовувати функціональні обов'язки, а також аналіз професійних навчальних ситуацій, дискусія, рольова і ділова гра, методичні прийоми «акваріум», «мозковий штурм», «круглий стіл», вправи, прийоми контролю та самоконтролю. На думку Н. Костриці (Костриця, 2005, с. 15), сутність ділової гри полягає у відтворенні предметного й соціального змісту конкретної професійної діяльності, моделюванні основних умов і 
системи відносин, які є характерними для цієї діяльності. Вона проводиться за заздалегідь розробленим сценарієм, а також певною моделлю, яка складається з таких етапів: підготовка учасників гри; вивчення ситуації, інструкцій, настанов та інших додаткових матеріалів; проведення гри; аналіз, обговорення й оцінювання результатів гри.

Їх застосування дає змогу максимально наблизити освітній процес до практичної діяльності, враховувати реалії сьогодення, ухвалювати рішення в умовах екстремальних ситуацій, відстоювати власні пропозиції, розвивати в учасників гри колективізм і відчуття команди, отримати результати за досить обмежений час.

Висновки та перспективи подальших наукових розвідок. Розвиток фахової компетентності НФПіС є важливим завданням сучасної військової освіти, вирішення якого передбачає розроблення й застосування спеціальної методики. Ефективність запропонованої методики її розвитку може бути підвищена шляхом упровадження в освітній процес спецкурсу «Основи фахової діяльності НФПіС». Основними видами навчальних занять під час вивчення спецкурсу є семінарські та практичні заняття.

Розроблена авторська методика сприятиме систематизації та поглибленню теоретичних знань, розвитку загальних і специфічних фахових здібностей, що єосновою їх фахової компетентності. Пропонується реалізацію методики здійснювати в чотири етапи: ціннісно-мотиваційний; теоретичний; практичний; творчо-рефлексивний. Перспективою подальших досліджень слід вважати розроблення методичних рекомендацій до вивчення спецкурсу «Основи фахової діяльності НФПіС».

\section{ЛІТЕРАТУРА}

Гончаренко, С. У. (1997). Український педагогічний словник. Київ: Либідь. (Honcharenko, S. U. (1997). Ukrainian Pedagogical Dictionary. Kiyv: Lybid).

Бибик, С. П., Сюта, Г. М. (2005). Словник іншомовних слів. Тлумачення, словотворення та слововживання. Харків: Фоліо. (Bybyk, S. P., Siuta, H. M. (2005). Dictionary of foreign words. Interpretation, word formation and vocabulary. Kharkiv: Folio).

Ягупов, В. В.(2000).Управлінські функції офіцера та їх педагогічний зміст. Вісник Української академії державного управління при Президентові України, 2, 307312. (Yahupov, V. V. (2000). Leadership functions of the officer and their pedagogical content. Bulletin of the Ukrainian Academy of Public Administration under the President of Ukraine, 2, 307-312).

Шиян, Б. М. (2008). Теорія і методика фрізичного виховання школярів. Частина I. Тернопіль: Навчальна книга - Богдан. (Shyian, B. М. (2008). Theory and methodology of students physical education. Part I. Ternopil: The Educational Book - Bogdan).

Бойко, О. В. (2005). Формування готовності до управлінської діяльності у майбутніх магістрів військово-соціального управління (дис. ... канд. пед. наук: 13.00.04). Київ (Boiko, O. V. (2005). Formation of readiness for management activity in future masters of military-social management (PhD thesis). Kyiv).

Селевко, Г.К. (1998). Современные образовательные технологии. Москва: Народное образование. (Selevko, G. K. (1998). Modern educational technologies. Moscow: Folk Education). 
Шинкарук, В.І. (2002). Філософрький енциклопедичний словник. Київ: Абрис. (Shynkaruk, V. I. (2002). Encyclopedic Dictionary of Philosophy. Kyiv: Abrys).

Круцевич, Т. Ю. (2008). Теорія і методика фізичного виховання. Загальні основи теорії і методики фізичного виховання. Том 1. Методи, що застосовуються у фізичному вихованні (сс. 104-106). Київ: Олімпійська література (Krutsevych, Т. Ү. (2008). Theory and methodology of physical education. General basics of the theory and methods of physical education. Volume 1 . Methods used in physical education (pp. 104-106). Kyiv: Olympic Literature).

Ягупов, В. В. (2000). Творче використання ділових ігор у навчанні військовослужбовців. Педагогіка і психологія фрормування творчої особистості: проблеми і пошук. Збірник наукових праць, 16, 124-127. (Yahupov, V. V. (2000). Creative use of pedagogical games in the training of military personnel. Pedagogy and psychology of creative personality formation: problems and search. Collection of scientific works, 16 , 124-127).

Гапоненко, Г. М., Гапоненко, С. Г., Погребняк, Д. В., Родіков, В. Г., Шемчук, В. А. (2018). Інтерактивне навчання: передумови, мета та сутність. Social and Economic Aspects of Education in Modern Society, 20, 45-46. (Haponenko, H. M., Haponenko, S. H., Pohrebniak, D. V., Rodikov, V. H., Shemchuk, V. A. (2018). Interactive Learning: Prerequisites, Purpose and Essence. Social and Economic Aspects of Education in Modern Society, 20, 45-46).

Сіроштан, О. В. (2012). Інтерактивні методи навчання в процесі професійної підготовки майбутніх соціальних працівників. Соціальна педагогіка: теорія та практика, 1, 85-90. (Siroshtan, 0. B. (2012). Interactive training methods in the process of professional training of future social workers. Social Pedagogy: Theory and Practice, $1,85-90)$.

Стасюк, В. В. (2013). Використання освітніх технологій як напрям покращення якості підготовки військових фахівців. Вісник Національного університету оборони України, 2, 142-146. (Stasiuk, V. V. (2013). Use of educational technologies as a way of improving the quality of military specialists training. Bulletin of the National University of Defence of Ukraine, 2, 142-146).

Наказ Міністерства оборони України від 20.07.2015 № 346 «Про затвердження Положення про особливості організації освітнього процесу у вищих військових навчальних закладах Міністерства оборони України та військових навчальних підрозділах вищих навчальних закладів України» (Order of the Ministry of Defence of Ukraine as of 20.07.2015 No. 346 "On approval of the Regulation of the educational process organization in higher military educational institutions of the Ministry of Defence of Ukraine and military educational units of higher educational institutions of Ukraine". Retrieved from: https://zakon.rada.gov.ua/laws/show/z1126-15).

Костриця, Н. М. (2005). Ділові ігри в підготовці фрахівців до управлінської діяльності. Київ: Науково методичний центр аграрної освіти (Kostrytsia, N. M. (2005). Pedagogical games in preparation of experts for management activity. Kyiv: Scientific and M ethodological Center for Agrarian Education).

\section{PEЗЮME}

Погребняк Дмитрий, Коновалов Денис. Методика развития профессиональной компетентности начальников физической подготовки и спорта военных частей Вооруженных сил Украины в системе последипломного образования.

Статья посвящена теоретическому обоснованию авторской методики развития профессиональной компетентности начальников физической подготовки 
и спорта воинских частей Вооруженных сил Украины в системе последипломного образования. Методы исследования: анализ научной литературы; обобщение и интерпретация полученных теоретических и эмпирических данных; проэктирование методики развития профессиональной компетентности. Раскрыты основные этапы методики: ценностно-мотивачионный; теоретический; практический; творческо-рефлексивный. Предложенная методика будет способствовать углублению и систематизации теоретических знаний, развития практических навыков, умений и способностей.

Ключевые слова: профессиональная компетентность, развитие, методика развития, начальник физической подготовки и спорта, этапы, методы, средства.

\section{SUM M ARY}

Pohrebniak Dmytro, Konovalov Denys. Methods of professional competence development of the heads of physical training and sports of military units of the Armed Forces of Ukraine in the system of postgraduate education.

The aim of the article is to substantiate theoretically the authors' methodology for developing professional competence of the heads of physical training and sports of military units of the Armed Forces of Ukraine in the system of postgraduate education (hereinafter HPTSM U) in the system of postgraduate education.

The following research methods were used in writing of the article: analysis of scientific literature on the problem of research; finding out the current state of functioning of the HPTSMU professional training system; generalization and interpretation of theoretical and empirical data obtained in the process of research; designing methods for the development of HPTSM U professional competence in the system of postgraduate education.

Results of the research. In the process of developing the methodology, the basic provisions of systems, competence, andragogic, subjective and contextual approaches, requirements of general didactic and specific principles of training were taken into account. The main stages of the methodology are revealed: value and motivational (aimed at increasing motivation for professional activity and stimulating activity in education); theoretical (focused on expanding and deepening professional knowledge); practical (aimed at developing professional skills and abilities on the basis of acquired theoretical knowledge); creative and reflexive (aimed at development of general and special professional skills and abilities of objective self-assessment in the ordinary and extreme conditions of military and professional activity). It is determined that the effectiveness of the proposed methodology can be enhanced by the use of technology of interactive, problem-oriented education and introduction into the training process of the special course "Fundamentals of HPTSMU professional activity". The main types of lessons during the special course are seminars and practical classes.

Conclusions. The technique proposed by the author will contribute to the deepening and systematization of theoretical knowledge, development of practical skills and abilities for the successful fulfillment of their duties in military and professional activity. The prospect of further research should be development of methodological recommendations for the study of the special course "Fundamentals of HPTSMU professional activity".

Key words professional competence, development, development methodology, head of physical training and sports, stages, methods, means. 